advocates the use of 'Cyanogas'*, and this to us seems the soundest proposal as yet formulated. Cyanogas is calcium cyanide in dust form, and this in contact with ground moisture or water vapour gives off hydrocyanic acid gas, which is the most deadly fumigant known. It is quite safe to handle in the portable foot machine, and the method is to blow a few puffs into the mouth of a warren, their number depending on its size, and then to close up and stamp down every hole with the spade, and leave the warren, into which dogs had previously driven all wanderers. The Cyanogas takes up to a day to decompose and is all this time giving off its gas, which diffuses so well that it penetrates to every part of the burrow.

Mr. Stead's figures are convincing, and his claim that this fumigant gives "the greatest kill possible" and entails "the least possible use of time and energy" seems justifiable; certainly at the esti-

- The Rabbit in Australia : History, Life Story, Habits, Effect upon Australian Primary Production and Best Means of Extermination. By David G. Stead. Pp. 108. (Watson's Bay, N.S.W.: The Anthor; London: University of London Animal Welfare Society, 1935.) 28 net. mated cost of $6 d$. per acre (or even at four times as much !) its use means "the lowest cost". In Australia it is claimed that the better sheep lands could be thus safeguarded, and their extra productiveness in wool and flesh would mean a handsome profit on the deal. Is it not also equally applicable to England, where rabbits have been selling everywhere in the country at $6 d$. a piece or less in the past winter? The shooting of rabbits is poor sport, and the eaten-off crops that surround many fields mean often a loss of 10 per cent of the crop of a farm, and must be abolished, if farming is to pay. No doubt the Ministry of Agriculture is alive to the use of Cyanogas, but in our experience few farmers or land owners know of it, and those who do mostly regard its use as highly dangerous. It is a fumigant applicable to the brown rat and perhaps the musk-rat, but in each case it requires to be used according to the mode of life of the beast. In any event, there is some hope now that these rodent pests may be controlled.
J. S. G.

\title{
Obituary
}

\section{Prof. James Rice}

JAMES RICE, who died on April 17 at the age $\mathcal{J}$ of sixty-two years, was associate-professor of physics and reader in theoretical physics in the University of Liverpool. He was educated at the Royal Academical Institution, and the Queen's College, Belfast (now the Queen's University, Belfast), where he obtained the highest honours (Senior Scholarship and Dunville Studentship). In the Royal University of Ireland his career was equally distinguished (scholar, student and junior fellow), and at the examinations for the B.A. and M.A. degrees and the junior fellowship he was awarded the highest place in the first-class honours list in mathematical science. In 1902 he was appointed senior physics master at the Liverpool Institute, a post which he held until 1914, when he was appointed to a senior lectureship in physics in the University of Liverpool. In 1924 the University of Liverpool conferred on him the title and status of associate-professor, and in 1935 the additional title and status of reader in theoretical physies.

In the earlier part of his career, Rice was particularly attracted to those branches of mathematical physics which deal with thermodynamics, kinetic theory and classical statistical mechanics, and soon obtained a mastery of all these subjects. Being gifted with a keenly receptive and flexible mind as well as an outstanding ability in mathematical science, he soon became an enthusiastic and expert student of the new advances in theoretical physicsPlanck's theory of the quantum of action, the
Robb-Einstein-Minkowski theory of relativity, the Rutherford-Bohr theory of the atom, and the later advances in the quantum mechanical theory of atomic and molecular events due to Heisenberg, Born, Schrödinger, Bohr, Dirac and Weyl.

Rice's early mastery of the general theory of relativity was demonstrated in the clearest fashion by the publication in 1923 of his "Relativity; a Systematic Treatment of Einstein's Theory" (Longmans, Green and Co., Ltd.). Although not intended to compete with the great treatise of Eddington (from whom Rice's work received a highly favourable notice in the columns of this journal), this book dealt in a thoroughgoing fashion with the complete mathematical theory of the subject, and soon became the best text-book in the English language for serious university students of theoretical physics.

Being convinced of the fundamental importance of the new outlook on science and philosophy due to the concepts of the modern theory of relativity, Rice became a devoted advocate of these views and gave highly appreciated 'popular' lectures thereon in many parts of the country, being invited by the Parliamentary Science Group to expound the new ideas to the members. His book on relativity in Benn's well. known sixpenny series had an immense sale, and probably did more than any other work on the subject to spread the new concepts among the thinking and more intelligent sections of the British public. Throughout his whole life, Rice was an enthusiastic and expert apostle of the new and wonderful light that had come into the minds of 
men. In his spirit there burned the pure and bright flame of a passion for knowing and for teaching those who would also know. Like those Irishmen of olden times who went forth to spread a new light throughout the world, he, too, felt he had a mission, and dedicated his life to it with a selfless devotion that had in it the same saintly quality.

Another example of Rice's mastery of the principles of modern theoretical physics is his "Introduction to Statistical Mechanics for Students of Physics and Physical Chemistry" (Constable and Co.), which was published in 1930. He had long contemplated a very comprehensive and advanced work on this subject, and had made many preparations for it, but the heavy calls on his time and strength made by his teaching work obliged him to confine his efforts to a smaller work. Nevertheless, Rice's "Introduction" has established itself in the affections of students of science throughout the world, and forms a very necessary and admirable preparation for a study of the advanced treatises of Fowler and of Brillouin, and the classical work of Willard Gibbs.

Prof. W. C. McC. Lewis, of the University of Liverpool, would be one of the first to acknowledge the valuable help he has received from Rice on many occasions. Students of his well-known treatise on physical chemistry will recollect the valuable contributions made by Rice to that important work.

Prof. Rice took a large part in the teaching of physics at the University of Liverpool. Besides lecturing to the advanced honours students, he gave for many years general courses on physical science, organised and supervised much of the practical laboratory work and was responsible for inspiring and guiding the work of many research students. Partly owing to his late entry into university work and largely owing to his wholehearted and unselfish devotion to the teaching of his students-and many of his friends of maturer age-he allowed himself little time for making personal advances in theoretical physics. Although he published a number of scientific papers, he will be chiefly known for his valuable books, which are gems of lucid scientific exposition of difficult branches of mathematical physics. $\mathrm{He}$ took an active part in the work of the Education Department of the University of Liverpool, for which his experience in teaching at the Liverpool Institute gave him special qualifications.

Rice cared much for the sorrows and troubles of his fellow-men, and took a deep and expert interest in the conditions of life and economic welfare of the workers in all classes of society. His warm heart and generous spirit could not tolerate any form of social injustice, and led him to take an active part in the work of the local branch of the Fabian Society.

Keeping himself constantly abreast of the newest advances in physical science, Rice possessed a marvellous power of assimilating this knowledge and explaining it to others. His constant aim at the University was to infuse the work of his students from the very beginning with the new concepts and principles of physics, rather than to ask students to unlearn their earlier knowledge and attack these fundamental matters as 'advanced work' in the later stages of their university life. Many generations of students both at the Liverpool Institute and at the University of Liverpool must owe him a very deep debt of gratitude for his inspired and inspiring teaching and his constant devotion to their interests. Most nobly and faithfully did he carry on the tradition of his great teacher at Queen's College, Belfast, Prof. William Blair Morton.

It may not be indiscreet to mention that an elaborate commentary on the scientific writings of J. Willard Gibbs will be published this year by the Yale University Press. In this commentary Prof. Rice was invited to participate, and contributed very important and valuable articles dealing with Gibbs's thermodynamical theory of heterogeneous equilibrium involving strained elastic solids and surfaces of discontinuity. In this work Rice returned to his earliest love, and demonstrated his complete mastery of two of the most difficult and recondite branches of thermodynamical science. It is sad to think that he will not see the publication of important work that cost him several years of intense thought—work that is surely destined to add further lustre to his reputation.

We, his many friends who live to mourn him, treasure in our hearts the memory of a sincere and affectionate friend and an eager, generous and unselfish spirit. $\mathrm{He}$ is survived by his devoted wife, but leaves no family.

F. G. DonNan.

DR. Ludwig DöderLeIN, formerly keeper of the Zoological Museum in Strassburg, died at Munich on March 23, 1936, aged eighty-one years. He graduated as Ph.D. at Bonn in 1877 , with a thesis on the skeleton of a tapir. He visited Japan, and there collected many fishes, which were described by Dr. Franz Steindachner and himself in the memoirs of the Vienna Academy of Sciences between 1883 and 1887. In 1889 he co-operated with Prof. G. Steinmann in a text-book, "Elemente der Paläontologie", and afterwards devoted himself chiefly to the study of fossil vertebrates. His latest papers on pterodactyls were published by the Bavarian Academy of Sciences in 1929.

Prof. Anton GHON, formerly director of the Pathological-Anatomical Institute of the German University of Prague, died on April 23 at the age of seventy-one years. He had specialised in the treatment of tuberculosis, and had discovered, during his collaboration with Sachs, the so-called Ghon-Sachs bacillus. He was interred at his birthplace, Villach, in South Austria.

WE regret to announce the following deaths :

Mr. H. G. G. Payne, director of the British Archæological School in Athens, on May 8, aged thirty-four years.

Sir Alfred Watson, K.C.B., Government actuary, who was president of the Institute of Actuaries in 1920-22, on May 7, aged sixty-six years. 